og National Institutes of Health (NIH) er godt oppsummert og lett tilgjengelig for den enkelte kliniker. Avslutningsvis er det gode kapitler om strategier for forebygging av cøliaki og alternative behandlingsmetoder

Vi vet i dag at cøliaki er en meget vanlig sykdom med insidens på rundt $1 \%$ i alle befolkninger som spiser hvete. Sykdommen gir en rekke kliniske tegn, hvorav mange ikke gir assosiasjon til tarmsykdommer. Diagnostisk forsinkelse er derfor vanlig. Diagnosen er oftest lett tilgjengelig når spørsmålet først er reist, men mange er usikre på hvilke roller serologi og biopsi skal spille i utredningen. Et vanskelig spørsmål oppstår når den kliniske mistanken om cøliaki er stor, men serologisk undersøkelse ikke støtter mistanken. Pasientene med cøliaki har ofte mange gode spørsmål om sin sykdom og håndteringen av den - men får ikke alltid gode svar. Denne boken vil hjelpe behandlere, det være seg leger, kliniske ernæringsfysiologer eller andre grupper, til å gi bedre svar.

Boken tar ikke mål av seg til å tilby uttømmende oversikter over de enkelte feltene, men den presenterer en imponerende mengde data på relativt beskjeden plass. Den er lett å lese og kan anbefales for et ganske bredt publikum.

Knut E. A. Lundin

Medisinsk avdeling

Rikhospitalet

\section{Knapt om bruk av sonder, dren og kanyler}

Brooks A, Mahoney P, Rowlands B, red. $A B C$ of tubes, drains, lines and frames 88 s, tab, ill. Oxford: Wiley-Blackwell, 2008. Pris GBP 20

ISBN 978-1-4051-6014-8

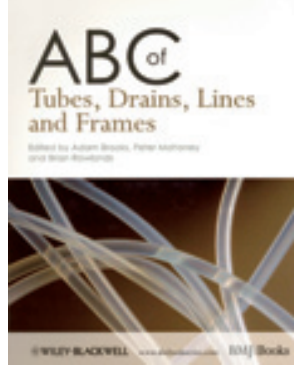

Det foreligger en rekke bøker i den såkalte «ABCserien» fra $\mathrm{BMJ}$ Books utgitt av Wiley. De fleste er beregnet for allmennpraktikere, studenter, leger i utdanning, og sykepleiergrupper.

Denne ABC-boken er også rettet mot denne gruppen, men kanskje i noe større grad også mot pleiergruppen og utdanningskandidater i kirurgiske fag, samt til allmennpraktikere som overtar deler av postoperativ omsorg, der dette er aktuelt.

I boken omtales og beskrives bruk av en rekke kanyler, dren, tuber, sonder, bandasjer og enkelte andre remedier som benyttes i forbindelse med sår eller kirurgisk behandling. De 13 kapitlene er enten delt inn etter anatomiske forhold («the chest» og «hepatobiliary»), utstyr («lines», «stomas» og «surgical drains») eller kirurgisk problemstilling («the complex abdomen» og «surgical airways»). Kapitlene er enkle og konsise, med flere fargeillustrasjoner og tekstbokser som fremhever budskapet. Dette er samtidig ulempen med fremstillingen: det kan bli vel knapt og betont fra forfatternes vinkel. I tillegg er den preget av det som er vanlig i britisk helsevesen, noe som ikke alltid er overførbart til norske forhold. De færreste norske utdanningskandidater ville vel vite hva et Jackson-Pratt-dren eller et Penrose-dren er?

Forfatterne starter noe merkelig med kapitlet om «the complex abdomen» som bl.a. inkluderer åpen buk etter skadekontrollerende kirurgi, hvordan legge en «vac-pac» og plassering av stomier. Kapitlet er velillustrert, men meget kortfattet hva gjelder teksten. Mer fyldig, men fortsatt konsist, er håndtering av kirurgiske luftveier (som likevel nå i all hovedsak håndteres av intensivleger de fleste steder). Det hadde kanskje vært mer hensiktsmessig å starte med «utstyrskapitlene», og deretter ta for seg mer problemorienterte kapitler suksessivt.

Kapitlet om smerte inneholder vel mange patofysiologiske illustrasjoner og flytdiagrammer i forhold til den prosedyremessige tilnærmingen som tilstrebes. Gjennomgående i kapitlene presenteres lister med for eksempel komplikasjoner forbundet med prosedyre, hvor disse utelukkende fremstår som opplisting uten «vanligste» eller «sjeldne» eller prosent/forekomst, noe som svekker fremstillingen. Boken avsluttes med ett kapittel om basis for måling av hjernetrykk, samt et kapittel kalt «frames, pins and plaster» som omhandler ortopedenes bruddbehandling med pinning, fiksering, og gipsing på knappe fire sider - noe som blir for lite omfattende i alle tilfeller.

Som en introduksjon til dagligdagse dippedutter som benyttes på sykehusavdelinger er dette en grei innføring. Behovet for strukturert kunnskap rundt dette er absolutt til stede i undervisning av studenter og kandidater. Imidlertid ville jeg heller foretrukket å se gjennom filmsnuttene på de ulike former for prosedyrer som nå er tilgjengelig på hjemmesiden til for eksempel New England Journal of Medicine (1) for innsikt og kunnskap om bruk av dren, tuber, sonder og kanyler. Disse filmene er både mer informative og morsommere å se på.

\section{Kjetil Søreide}

Kirurgisk avdeling

Stavanger universitetssjukehus

\section{Litteratur}

1. McMahon GT, Ingelfinger JR, Campion EW. Videos in clinical medicine - a new journal feature. $N$ Engl J Med 2006; 354: 1635

\section{Helse for nesten alle?}

Hogstedt C, Moberg H, Lundgren B et al, red. Health for all?

A critical analysis of public health policies in eight European countries. 356 s, tab, ill.

Östersund: Statens folkhälsoinstitut, 2008.

Pris SEK 250

ISBN 978-91-7257-572-1

I 2003 vedtok Riksdagen ein omfattande strategi for den svenske folkehelsepolitikken med 11 definerte målområde. Boka er blitt til som ledd i oppfølging av denne. Folkhälsoinstitutet har gjennomgått sentrale dokument for folkehelsepolitikk i åtte europeiske land med særleg vekt på arbeid for helsemessig likskap og likeverd (equity), slik status var per 2006. Vitskaplege ekspertar frå kvart av dei åtte landa har medverka i prosessen. Norsk representant er Elisabeth Fosse ved HEMIL-senteret.

For den som er interessert i temaet helse og ulikskap, er det mye interessant stoff å finne. Rikhaldige referanselister gir god vegleiing til vidare lesing. Gode, men ikkje spesielt talrike, diagram og tabellar supplerer teksten.

Eitt kapittel for kvart av dei åtte landa utgjer tre firedelar av omfanget. Desse vil nok for dei fleste lesarane vere mest nyttige som oppslagsstoff, dersom ein skulle vere særleg interessert i situasjonen i til dømes Italia eller Nederland. Innleiings- og avslutningskapitla eignar seg meir for lesing frå første til siste side. Her finn ein gode oppsummeringar om prinsipp, definisjonar, metodikk, fallgruver og perspektiv innan fagfeltet helse og ulikskap. Som definisjon av «equity in health» blir det brukt den som er gitt av Society for Equity in Health: «The absence of systematic and potentially remediable differences in one or more aspects of health across population groups defined socially, economically, demographically, or geographically.»

Den politiske tilnærminga i ulike land kan delast $\mathrm{i}$ tre grupper: vektlegging av dårleg helse hos sosioøkonomisk svakstilte grupper (som i Italia), helseskilnader mellom ulike grupper (England) eller ein kontinuerleg helsemessig gradient gjennom heile befolkninga (Noreg). Medan Spania, Frankrike og Hellas ikkje ser ut til å ha nokon offentleg politikk knytta til helse og ulikskap.

Interessa for temaet helse og ulikskap har i seinare år fått ein renessanse i mange land. Denne boka gir eit europisk perspektiv på problematikken, og er eit fint supplement til publikasjonar om gradientutfordringa frå Helsedirektoratet her i landet. Men, som det lakonisk heiter i teksten, det har hittil vore meir fokus på status og årsaker enn på intervensjon.

\section{Kristian Hagestad}

Helsetilsynet i Vest-Agder Kristiansand 